\title{
List of contributors
}

Sunil S. Amrith is Lecturer in History in the Department of History, Classics and Archeology at Birkbeck College, University of London.

C. A. Bayly is Vere Harmsworth Professor of Imperial and Naval History, and Fellow of St Catharine's College, University of Cambridge.

Keith Breckenridge is Associate Professor of History in the Department of History at the Howard College Campus of the University of KwaZulu-Natal.

David Hall-Mathews is Senior Lecturer in International Development in the School of Politics and International Studies at the University of Leeds.

Tim Harper is Reader in History, and Fellow of Magdalene College, University of Cambridge.

Ravi Kanbur is T. H. Lee Professor of World Affairs, International Professor of Applied Economics and Management, and Professor of Economics, Cornell University.

Uma Kothari is Professor of Development Studies at the Institute of Development Policy and Management, University of Manchester.

Stephen J. Kunitz is Professor Emeritus in the Department of Community \& Preventive Medicine, University of Rochester School of Medicine.

Mick Moore is Professorial Research Fellow at the Institute for Development Studies, Sussex.

Lant Pritchett is Professor of the Practice of Economic Development at the Kennedy School of Government, Harvard University. 
Vijayendra Rao is Lead Economist in the Development Research Group, World Bank.

Richard Smith is Professor of Historical Geography and Demography, and Fellow of Downing College, University of Cambridge.

Simon Szreter is Professor of History and Public Policy, and Fellow of St John's College, University of Cambridge and Founding Editor of www.historyand policy.org.

David Vincent is Professor of Social History at the Open University.

Paul Warde is Reader in Early Modern History in the Department of History, University of East Anglia.

R. Bin Wong is Professor of History and Director of the Asia Institute, University of California, Los Angeles.

Michael Woolcock is Lead Social Development Specialist in the Development Research Group, World Bank. During the period when much of the work for this book was undertaken, he was Professor of Social Science and Development Policy, and Research Director of the Brooks World Poverty Institute, at the University of Manchester. 